\title{
Teaching Theological English to Theology Students of IAKN Tarutung: What Students Need and How Lecturers Address the Needs
}

\author{
Rafita Tioria Sianipar \\ Institut Agama Kristen Negeri Tarutung \\ fitasianipar@gmail.com
}

\begin{abstract}
The goals of this article are to observe what the Theology students of Institut Agama Kristen Negeri (IAKN) Tarutung need to learn in their English class and to figure out what the English lecturer do to fulfill the need. The background of this article is based on the empirical study by the author who teaches Theological English for students in their first and second semesters at IAKN Tarutung. The author had noticed how General English (GE) was taught to Theology students, and it was revealed that learning GE did not make the students able to do what they were expected to, such as understanding English religious texts and Bible verses, delivering prayers in English, or even preaching in English. As Theology students who are required to do those things previously mentioned, they need to learn English for Specific Purpose, i.e. Theological English (TE) in this case. As it apparently was not easy to find materials that meet IAKN Tarutung's Theology students' need, the author, who is also the English lecturer, wrote her own materials in the form of a textbook (in collaboration with a professor of English studies) to be taught to IAKN Tarutung's Theology students. Writing and using the textbook entitled "English for Students of Christian Institution" in English classes for Theology students at IAKN Tarutung was suggested as the solution to fulfill the students' need of TE.
\end{abstract}

Keywords: Theological English, Theology students, "English for Students of Christian Institution

\section{Introduction}

In this 4.0 era, to master English is no longer an option but an obligation for everyone, including Theology students. For Theology students, English plays the essential role as a conveyor of knowledge about Christian to the international community and on the diverse ways in which global cultures, which are often accessible in English, would continue to connect with the religious world (Christian world in this context) (Dazdarević, 2012). Besides, as a language, English serves a media to worship, to praise and to recognize God's commandments (Palimbunga, 2016). Further, English is also used in contexts of worshiping (prayer, preaching and song), in theological discourse, in the context of religious experiences (witness and meditation) and in everyday life (blessing and cursing) (Darquennes \& Vandenbussche, 2011). Concerning how English takes an necessary role for theological things, it is doubtless that Theology students have to possess English skill. Especially as students whose mission is to spread God's words to all over the world, Theology students are required to master English as it is the most important tool in globalization.

In regards with English teaching and learning, as far as the author had noticed, Theology students of Institut Agama Kristen Negeri (IAKN) Tarutung had been taught General English (GE) in their English class. Based on the set of English lesson plans for Theology classes that 
the author received from one of the English lecturers at IAKN Tarutung, it was found that the students had been taught common materials which students generally learn at schools. They had been taught tenses along with the formulas, general vocabularies, and other topics which were not related to Christian studies. Regardless to mention that GE is not contributing anything to Theology students, it should be realized that GE does not provide what Theology students need. After learning English, Theology students are expected to be able to at least understand English religious texts and Bible verses, deliver prayers in English, and even preach in English. To fulfill these expectations, it is important for lecturers to teach proper English to those students, i.e. Theological English or Theological English (TE).

Studies dealing with TE has been conducted by only a few numbers of education practitioners all over the world. In United Kingdom, Pierson, Dickerson, \& Scott (2010) released their book "Exploring Theological English, Lecturer's Guide" as the result of their study on English for Bible and Theology (EBT). According to them, higher level students tend to improve more quickly when they are taught with materials and activities that focus on the content, dealing with their Bible and theology course work Besides, theu also need to focus on the discipline-specific language they are expected to master and those certain work they will have to fulfill in English. Still in UK, Yaghjian (2018) also managed a study on pedagogical challenges in teaching English for Second or Other Language (ESOL) students writers in theology education. Her study suggests that the challenges in teaching ESOL in theology education can be solved by reflecting on those challenges, their context, and responses to them, connecting contemporary theories of ESOL language learning with the practice of teaching and tutoring non-native English writers in a theological context, and proposing a discipline-driven, writing-centered ESOL pedagogy. In addition, in Serbia, Dazdarević (2012) conducted a study on English for Religious Purposes which emphasizes the relationship between the English language and religion and its significance in contemporary times. The study suggests that English needs to be mastered by Theology students as the tool to convey Christian knowledge to the universe. In the meantime, in Indonesian, Palimbunga (2016) did a study on designing vocabulary materials for English for Theology course at Sekolah Tinggi Agama Kristen Negeri (STAKN) Toraja based on needs analysis. His study proposes that the topics that need to be learned by the students in English for Theology course at STAKN Toraja are: (1) Prayer, (2) the Ten Commandments , (3) the Apostle's Creed, (4) Holy Bible: Books of the Old Testament and Books of the New Testament, (5) God: The nature of God and the Attributes of God, (6) Jesus Christ: The person of Christ and The work of Christ (7) Holy Spirit:The work of Holy Spirit and The names of Holy Spirit, Man:The creation of man and The fall of man, (8) Church: Worship, and Sacrament, (9) Salvation :Repentance and Faith, (10) Last Things:The second coming of Christ and Judgement, and (11) The Prophets and The Apostles. The objectives of this study are as followings:

a. To observe what Theology students of Institut Agama Kristen Negeri (IAKN) Tarutung need to learn in their English class, and

b. To figure out what English lecturers do to fulfill the need.

\section{Result and Discussion}

\subsection{What IAKN Tarutung's Theology Students Need to Learn in Their English Classes}

\section{a) Needs analysis in Theology students' English class}


In terms of a linguistic deficiency, needs are usually defined as the distiction between students ' current level of capability in a language and what they are expected to master (Richards, 2001). To identify students' needs in English language teaching and learning, especially in college (where students are specifically majored in certain fields), lecturers must realize what the students require to face the professional world after college besides also considering the students' current level of English proficiency. When analyzed, needs can be described in terms of goals and objectives as the support for developing teaching materials, activities, tests, and strategies for evaluation (Brown, 1995). Hence, needs analysis is handled by lecturers to perceive what points of language their students need to learn.

Due to the lack of teaching sources, the author had spent her very first semester teaching GE to Theology students of IAKN Tarutung by adapting the set of lesson plans which was received from one of the senior lecturers. During the term, it was noticed that students could follow the lessons quite well, but when they were asked to lead prayers before or after classes in English, they were not confident at all. They had to concept the prayers and memorize them for days before really doing it in front of the class.

While even to deliver prayers was already considered difficult by them, of course it would not make sense to expect them to preach in English. They had no idea of what to say in prayers or short sermons since they had never learned theological vocabulary. This certainly had caused a great concern to the lecturer. How could Theology students be not able to lead prayers or deliver even short sermon? Then this would have made the English class for the whole semester good-for-nothing. Began with this issue, then it was decided that Theology students of IAKN Tarutung needs to study English for Specific Purposes, i.e. Theological English.

\section{b) General English vs English for Specific Purposes}

General English (GE) or General Purpose English refers to the common core of language skill essentials for learners from all disciplines (Pierson et al., 2010). Students all over the world usually study the same basic English skills (reading, writing, speaking, and listening) in GE. Various tenses are commonly taught to students as top topic of grammar, followed by bundles of vocabularies to be used in daily communications. GE is learned by students from elementary to high school. GE contains grammar, vocabularies, spelling, pronunciations, etc. which serve to enable its learners to communicate both written and orally in English. English for Specific Purposes (ESP), on the other hand, can be perceived as the more specific version of GE which embodies practical linguistic skills to empower the students for the successful achievement of professional work (Potocar, 2002). ESP can be said as classified English materials which are designed to cover the requirements of what certain students have to master in order to survive the professional world. College students, who are already majored in certain fields, should study ESP to prepare themselves for their future carreer. Since students in Indonesia have spent 12 years learning GE at school, then it should be the right time for them to not meet GE again at college, but ESP instead.

The contrast between GE and ESP actually lies in the way we specify and carry out the learning purpose itself. While GE's target does not associate to the particular objective concerning the development of general capability (in educational program), ESP's target, on the other hand, relates to the specific objective dealing with the development of defined expertise (in training program) (Widdowson, 1983 cited in Ajideh, 2009). In ESP, the context in which the language is learned is of considerable relevance to the kind of English students will want and need to study, and the skills they will need to acquire (Harmer, 2007). In other words, GE 
is learned to obtain common proficiency of English, while ESP is studied to gain trained skills for their carreer.

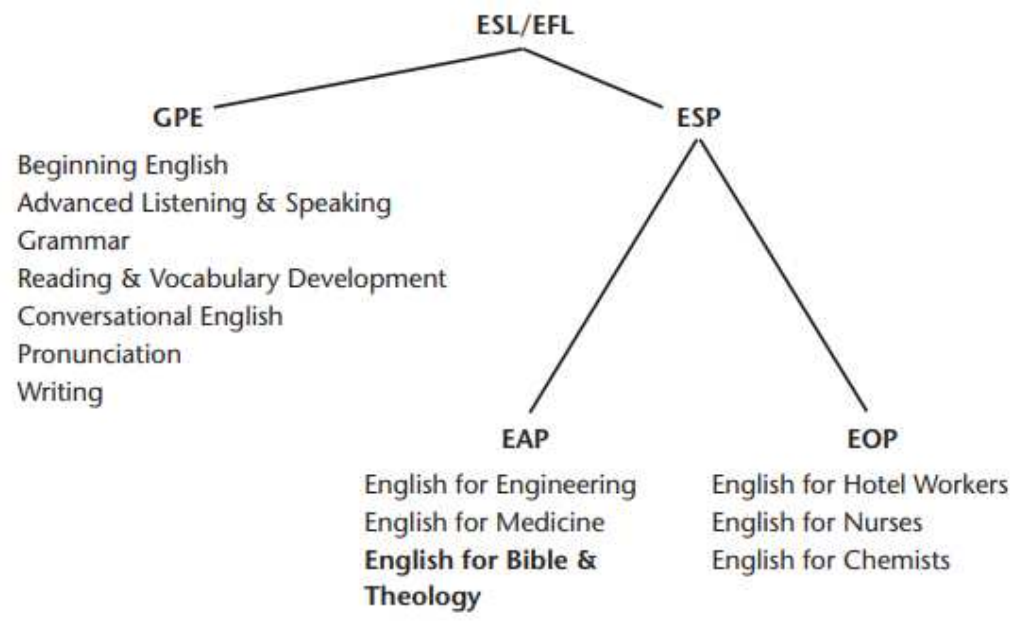

Fig.1. Categories of ESL/EFL Teaching and Learning (taken from Pierson et al., 2010)

\section{c) Theological English for IAKN Tarutung's Theology students}

English for Theology centers on aspects of English relevant to theological studies, including theological terms, the scope of complex sentence structures used in theological writing and patterns used by theologians in their teaching and writing (Pierson et al., 2010). Therefore, in TE, the main target is not to dig in Theology theories, but to get the students used to using English in delivering their theological ideas. As for Theology students of IAKN Tarutung, TE needs to be brought to the students in a complete package containing theological vocabularies, prayers, short sermon concepts and practices, Bible storytelling, theological idea sharing without judging, etc. If Theology students study and master all those materials, there would be no doubt that they could be qualified theologists in the future.

\subsection{What English Lecturers Do to Fulfill IAKN Tarutung's Theology Students' ${ }^{6}$ Need: A self-made "English for Students of Christian Institution" Textbook}

To prepare qualified future theologists, English lecturer must provide qualified learning materials for the students. In determining the materials, lecturer should be able to identify an overall purpose or goal that the class will attempt to accomplish by the end of the classs period (Brown, 2001). In one way, it is easiest for a lecturer to simply adopt a textbook and begin teaching systematically through the prepared materials, but on the other hand, lecturers cannot easily find a textbook that really matches their classroom needs (Brown, 1995). Thus, English lecturers of IAKN Tarutung (one of those is the author herself) decided to be self-developed language lecturers (see Gebhard, 2006) and created the materials by themselves to fulfill their Theology students' need of TE. They wrote a book entitled "English for Students of Christian Institution" (Sihombing \& Sianipar, 2018) whose contents have been adjusted to prepare the 
students to be qualified future theologists and to meet their students' level of English capacity. This book has been used for 2 semesters in TE classes.

Below are the topics and materials that were included in "English for Students of Christian Institution" book (all pictures of examples are taken from that book):

\section{a) Theological vocabularies}

which covers the books of Old Testaments, prophets' and other Biblical characters' names, crossword puzzle, synonyms and antonyms, etc. These vocabularies can be used by the students in their prayers or sermons.

\begin{tabular}{|c|c|}
\hline \multicolumn{2}{|l|}{ Exercise I } \\
\hline \multicolumn{2}{|c|}{$\begin{array}{l}\text { Match the names of the books on the left column with their } \\
\text { contents on the right column. }\end{array}$} \\
\hline Books & Contents \\
\hline 1. Exodus & a. the creation \\
\hline 2. Proverbs & $\begin{array}{l}\text { b. stories of a conglomerate who had } \\
\text { lost everything but still believed in God }\end{array}$ \\
\hline 3. Genesis & $\begin{array}{l}\text { c. the establishment of David as a king } \\
\text { whose line would rule forever }\end{array}$ \\
\hline 4. Lamentations & d. the Torah \\
\hline 5. Jonah & e. wisdom \\
\hline 6. Kings & f. stories of Solomon \\
\hline 7. 2 Samuel & $\begin{array}{l}\text { g. a lament for what occured to Judah } \\
\text { and Jerusalem }\end{array}$ \\
\hline 8. Job & $\begin{array}{l}\text { h. announcement that a messiah will } \\
\text { emerge }\end{array}$ \\
\hline 9. Isaiah & $\begin{array}{l}\text { i. stories of a prophet who was eaten } \\
\text { by a fish }\end{array}$ \\
\hline
\end{tabular}

Fig.2. Example of Theological Vocabulary Exercise

\section{b) Grammar}

which facilitates the students to practice all GE grammar that they have learned at school and relate it to theological contexts. 


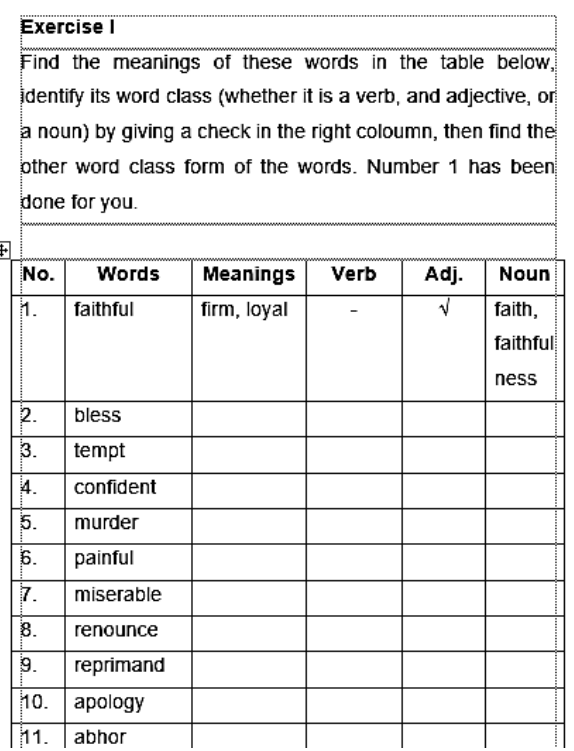

Fig.3. Example of Grammar Exercise

\section{c) Theological conversations}

Which lets the students to practice before they make their own conversation.

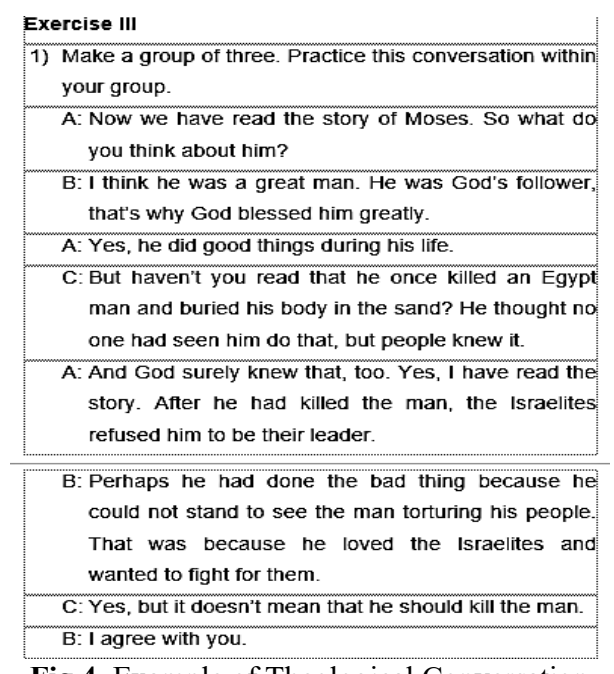

Fig.4. Example of Theological Conversation

\section{d) Theological idea sharing without judging}

Questions on the exercises are designed in such a way that allow students to express their opinions about what happens from the Bible. Their answers will not be judged as right or wrong, because the main focus is to let students speak out their mind. 


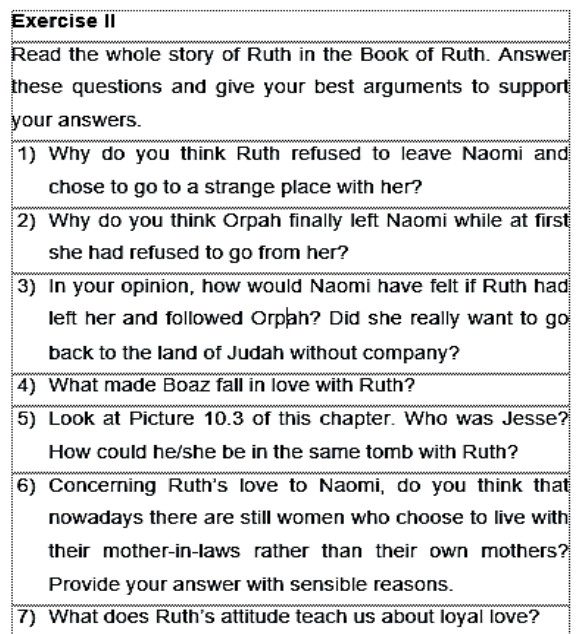

Fig.5. Example of Theological Idea Sharing without Judging Exercise

\section{e) Biblical writing practices}

In every chapter of the book, students are instructed to write a short essay about their opinion on a certain topic.

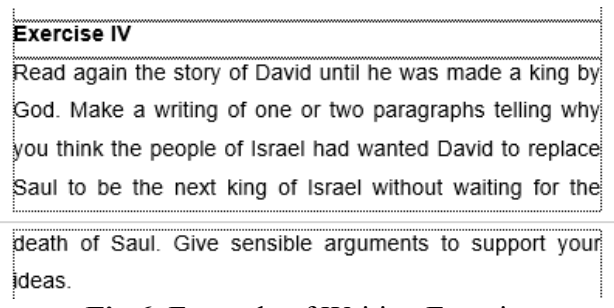

Fig.6. Example of Writing Exercise

\section{f) Bible stories}

Every chapter provides different story of different Biblical character which can be a model for the students to write their own Bible stories. 


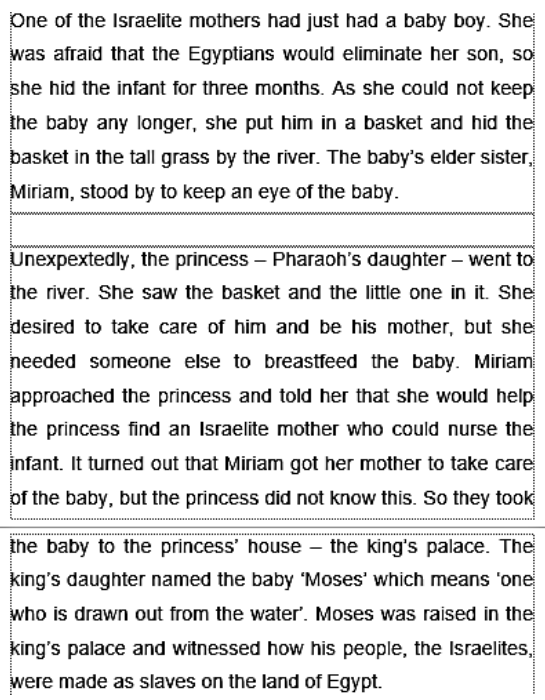

Fig.7. Example of the Bible Story

Designing lecturers' own materials in a textbook for to match classroom use is surely not a small deal; it takes a huge efforts to deeply think about the questions and variations of exercise that might be valuable for the students. Despite all the difficulties, the effect of using own-made materials for TE worths the efforts. After using the book to teach TE to IAKN Tarutung's Theology students, it was affirmed that most of the students have become confident in learning TE. They can boldly come in front of the class to lead prayers even without preparing the concepts at home and memorizing them for days. In the end of last semester (even semester of academic year 2018/2019), students were expected to deliver a short sermon in English, and they could do it confidently. Their grammar might be flawed here and there but the what mattered most was that they used English confidently with understandable English. Considering this progress the students have made in their TE class, it is reasonable to say that IAKN Tarutung would produce qualified theologists in terms of English language skill in the future.

\section{Conclusion}

To conclude, Theology students of IAKN Tarutung are not supposed to learn GE; they require to learn ESP, i.e. TE in order to prepare them to be qualified theologists in terms of English language skill. English for Theology needs to be brought to the IAKN Tarutung's Theology students in a complete package containing theological vocabularies, prayers, short sermon concepts and practices, Bible storytelling, theological idea sharing without judging, etc.

Hence, to anwer the requirement, rather than adopting a textbook that does not exactly match the needs of the classroom use, English lecturers of IAKN Tarutung created their own textbook to teach to their students in TE classes. The book covers the materials of theological vocabularies, grammar, theological conversations, theological idea sharing without judging, biblical writing practices, and Bible stories. After using this textbook for two semesters, it was acknowledged that there were progress made by the students in ET class, and the most 
remarkable progress was that the students have become more confident in using English for theological use.

\section{References}

[1] Ajideh, P. (2009). Autonomous learning and metacognitive strategies in ESP class. English $\begin{array}{lllll}\text { Language } \quad \text { Teaching } & \text { 2(1).162-168. } & \text { Retrieved from }\end{array}$ http://www.ccsenet.org/journal/index.php/elt/article/view/354

[2] Brown, H. D. (2001). Teaching by principles: An interactive approach to language pedagogy. New York: Addison Wesley Longman, Inc..

[3] Brown, J. D. (1995). The elements of language curriculum: A systematic approach to program development. Massachusetts: Heinle \& Heinle Publishers.

[4] Darquennes, J., \& Vandenbussche, W. (2011). Language and religion as a sociolinguistic field of study: some introductory notes. Sociolinguistica 25/2011. International Yearbook of European Sociolinguistics, Language and Religion.

[5] Dazdarević, S. (2012). English for religious purposes. Teaching Foreign Languages for Special Purposes. Retrieved from https://www.researchgate.net/publication/282186580

[6] Gebhard, J. G. (2009). English as a foreign or second language: A self-development and methodology guide. USA: University of Michigan.

[7] Harmer, J. (2007). How to teach English. Edinburgh: Pearson Education Limited.

[8] Palimbunga, T. D. (2016). Designing vocabulary materials for English for Theology course at Sekolah Tinggi Agama Kristen Negeri (STAKN) Toraja based on needs analysis. TEFL Overseas Journal (2).87-104

[9] Pierson, C. L., Dickerson, L. J., \& Scott, F. R. (2010). Exploring theological English, teacher's guide. Carlisle: Piquant Editions.

[10] Potocar, M. (2002). ESP in Slovenian secondary technical and vocational education. English for Specific Purposes World Vol. 1. online journal available at: http://www.espworld.info/Articles_1/esp.html

[11] Richards, J. C. (2001). Curriculum development in language teaching. Cambridge: Cambridge University Press.

[12] Sihombing, L., \& Sianipar, R. T. (2018). English for students of Christian institution. Tarutung: IAKN Press.

[13] Yaghjian, L. B. (2018). Pedagogical challenges in teaching ESOL/multilingual writers in theological education. Teach Theol Relig. (21)162-176. DOI: 10.1111/teth.12438 